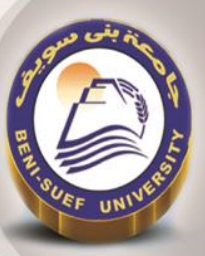

\title{
From Self-realization to Communal Identification: A Postmodern Reading of Toni Morrison's Song of Solomon and Beloved Dr. Amany Abdullah Abdel-Aziz Eldiasty*
}

\section{E-MaiL: amanyeldiasty@du.edu.eg}

$\quad$ ABSTRACT
ARTICLE INFO
Received 2020-08-23
Accepted 2020-12-11
Keywords
$\quad$ Freedom,
history, communal
identification,
folkloric elements,
Song of Solomon,
Beloved,
postmodernism

ABSTRACT

In Afro-American literature freedom has been a watchword that derives its essence from a deep awareness of history and a comprehensive sense of wholeness that both evolves within a full realization of a strong sense of responsibility. This paper aims at tracing the journey from self- realization to communal identification in Morrison's selected novels through shedding some light upon the significance of history and freedom in a postmodern society characterized by fragmentation, detachment, loneliness and displacement. The paper argues that freedom is only acquired when linked with a co-existent trend for integration, either vertical or horizontal. In Morrison's Song and Beloved, the communal element dominates the background of the action. The paper concludes that history evolves as a ruling principle that all the time has its own positive aspects that keep people safe providing them with a cultural identity that induces them with a personal one. Though freedom is a personal dream in the first place, it converts to nothing if isolated from the more comprehensive collective

\footnotetext{
${ }^{*}$ Lecturer, Damietta Faculty of Arts, Egypt
} 
communal vision. It needs the community to feed its hunger for support the same as it needs the individual to frame up its strife for distinction.

Unlike the postcolonial view of identity (Tajizadehkan and Ghasemi 2019) which redefines the self as subject to formation, this paper aims at investigating the journey from self- realization to communal identification in Afro-American novels through shedding light on the significance of history and freedom in a postmodern society characterized by fragmentation, detachment and dislocation. In Afro-American literature freedom has been a watchword that derives its essence from a deep awareness of history and a comprehensive sense of wholeness that both evolves within a full realization of a strong sense of responsibility. This paper argues that freedom is only acquired when linked with a co-existent trend for integration, either vertical or horizontal. A person is free only if absorbed in ancestral experiences on one hand, and if reacting with current ones on the other. As a result, love becomes an integral factor to be considered on both personal and communal levels. It is an essential temporal catalyst that inspires and connects past and present within one whole, proceeding toward a satisfactory future. So, it is the job of Afro-American authors to portray the Black odyssey for freedom in a world that finds its own freedom in nothing but in enslaving them. Here comes Toni Morrison with her Song of Solomon and Beloved to participate in such a portrait. She introduces Milkman, Pilate, Baby Suggs, Paul D., Denver and Sethe who end up the novels with an acquired identity that sets them free, each within a different context. 
In Morrison's writing, there is a constant attempt at glorifying the collective past of African Americans toward a manifestation of personal and cultural identity. She wants to pinpoint the fact that it is only through the past that people could feel 'oneness' with each other. It is only their ancestral experiences that could unite them; that could bind them all to their common roots within the African heritage flavored by the Afro-American experience in America. So, escaping from history, however painful it is, is excruciating and destructive. History should be internalized but should never be suppressed within. People should regard history as a part of their cultural and consequently their personal identity. Like many other Afro-American novelists, Morrison sees her work "as a means to extend [her] culture rather than to escape the racial injustice and brutality by whites" (Bruck, "Introduction" 4). For her, the Black man is no more a victim of white oppression; he himself has been a subject rather than an object of his own humiliation. Applying this to Beloved, Elizabeth Abel points out that Beloved represents slaves mainly "as subjects rather than objects of oppression." It is intentionally done in a "discourse on the hunger, passion, and violence generated in the 'too thick' mother-daughter bond produced by the conditions of slavery" (199). As a result, setting himself free is the Black man's own job for which he must assume responsibility.

In Song of Solomon, Milkman grows up when forced to discover his family roots. His journey toward freedom starts at his aunt Pilate's house. It is this first encounter with an alien world that anticipates his later quest. Being at Pilate's house makes him "more alive than he'd ever been" (Song 44). From this moment on, Milkman's process of maturation centers on the discovery of his ancestral roots. He moves to Danville and later to Shalimar, then to Virginia in search for the gold his father thinks Pilate has hidden in a cave there. Nonetheless, in Peter Bruck's words, "this treasure hunt turns into a parable of selfdiscovery" ("Returning to One's Roots" 294). In the first stage of his journey he meets two persons: Reverend Cooper and Circe, and he 
discovers that his grandfather's was 'Jake' and that his grandmother's name was 'Sing'. Though Milkman is unable at this stage to understand the significance of the two names, he is persuaded to carry on to Virginia where he thinks Pilate must have taken the gold.

In Beloved, Paul D is an ex-slave who used to move from one place to another till he has finally reached 124 Bluestone. His is also a journey of self-identification. He continues moving till he reaches the place where he could be re-introduced as a responsible post-modern hero in his journey of initiation. Through Milkman and Paul D, Morrison lines out the "shift in the mood of society at large, where the emphasis had veered from the mass struggle for black consciousness to the personal struggle for self-realization and affirmation" (HudsonWeems 7) that would in turn create a solid basis for a cultural and communal one. Finally, though representing two different stages of the Afro-American experience, Song of Solomon and Beloved hold as basic the existence of responsibility if freedom is ever to be reached. For that reason, the theme of the Ulysses journey is implied in Morrison's work, as "that going from town to town or place to place or looking out and over and beyond and changing-that's what they do. It is the Ulysses theme", they leave their home and embark on a process of making themselves. (Robert 222). It is the Black man's own responsibility to search for his roots and it is his responsibility to move along places till he reaches a place where his history is well nurtured and cared for.

In Song of Solomon, the final stage of Milkman's initiation takes place in Shalimar, a rural black community. Here, Milkman, the 'hero' coming from the North, is faced with hostility of his black brethren toward him. This hostility emerges because "[t]hey looked at his skin and saw it was black as theirs, but they knew he had the heart of the white men who came to pick them up in trucks when they needed anonymous, faceless laborers" (Song 265). So, it is the rural South that makes Milkman take a stand for the first time in his life, as he successfully defends himself. Though he had a fight with his father 
once before, the fight in Shalimar store leads him to a new state of selfawareness that flourishes only within the Southern black community. As the exit from the North and the concomitant entrance into the South conditions the hero's losing "the heart of the white men", so does his moving from a present cursed by the materialistic Western values for possession to a past blessed with a cultural purity and authenticity.

Though the geographical symbolism is reversed in Beloved, the spiritual move is not. The Sweet Home men/women leave from the South to the North, thinking that it is only in the North that they could be regarded as human. They leave behind all the destructive and humiliating sites of slavery. However, it is only through their 're-living' their past in the South that they acquire a new sense of 'selfhood'. Here comes the significance of the technical device of introducing the baby ghost. According to Deborah Horvitz, "Sethe's memory is being pried wide open by Beloved's presence. She forces Sethe to listen to her own voice and to remember her own mother, her ma'am with the special mark on her body, along with her mother's native language, songs and dances" (161). It is Beloved's arrival that generates in Sethe the force to speak what she had thought before to be unspeakable. It is her arrival that sets free all the repressed memories in Sethe's mind that kept her ages to feel alive.

Therefore, as "Milkman cannot become a complete being until he (re) connects the loose historical cords of his memory" (HudsonWeems 53), Sethe is unable to identify herself till she "re-members". Here the color imagery rules supreme in reflecting this idea. Sethe fails to identify colors till her past is re-created and lively embodied in the ghost's presence. Sethe "thought how little color there was in the house and how strange that she had not missed it. [...] It was as though one day she saw red baby blood, another day the pink gravestone chips, and that was the last of it" (Beloved 38-9). What Sethe is unable to tell is nothing but repressed memories "whose recollection and recreation are essential to her recovery" (Krumholz 395). Here, it comes clear that 
memory is essential for both Milkman and Sethe to achieve freedom. Though the source differs in each case, as it comes in the case of Milkman from the outside while it comes in the case of Sethe from the inside, it is the value itself that refers them back to life.

In both Song of Solomon and Beloved, history is the force that gives the present its true essence. Heavy-loaded, history is always drawing people by its electrons that paradoxically set them free supplying them with roots and ancestral heritage. In Song of Solomon and Beloved, history is, all the time, looming large in the background. Here Morrison wants to say that people should first 'reconnect' themselves to the past before they fix themselves into a certain present. In Song of Solomon, it is only when Milkman meets Pilate- the ancestral figure in the novel- that he learns about "the perfect matching". From Pilate, Milkman learns the importance of having a collective self to attach himself to. In fact, it is the egg-recipe image that frames up the theme of wholeness in the novel. Here, Pilate lets Guitar and Milkman know how to cook a soft-boiled egg in three minutes: "Now the water and the egg have to meet each other on a kind of equal standing. One can't get the upper hand over the other. So the temperature has to be the same for both" (Song 39). Milkman here is the egg and Guitar is the water. Both of them need equal matching to assume perfect control. The message here is that all barriers should be broken and one whole should emerge. Locating Guitar at a lower class serves the theme because though Morrison considers "class differences" to be an aspect of "mutual attraction", she recommends that characters' economic circumstances are not the only factor that "alienates [a] lower... class from a common culture"(Dixon 133). 
In addition, introducing Pilate into the scene serves to emphasize that flying functions as a black women's conjure, and not as a "black male industrial initiative" (Baker 105). In order to fly, i.e. to reach one's dream of freedom, there is another kind of wholeness that should be played on; this is the wholeness between men and women as members of one race. Women, who have been the scapegoats of the Afro-American society, are now to be fused into the same society as founders not servants. As Pilate pilots Milkman in his own journey, he returns to take her to Shalimar bringing her similar homelessness to an end. She blended easily into the population. Near the end of the novel, Milkman realizes the lesson of his ancestral past, which is: "In union with the whole [community], you can define the part [self]. In losing personal ego, you find it. Out of death comes birth. Most wonderfully, transcendence follows the discovery of the self" (Lee 359).

Pilate is the ancestral figure who has already framed herself some sort of identity embodied in her clinging to her past. In Pilate's story lie the values that she sustained herself with, and that she guided Milkman through throughout his own journey of initiation. Though she leads Milkman toward integration into the community, her own initiation has resulted in her isolation from it. She was cast out as an orphan whose navel-less belly became a physical indication of her loneliness. It was the community that made her revise her life altogether. When Pilate "realized what her situation in the world was and would probably always be she threw away every assumption she had learned and began at zero" (Song 149). She starts by deconstructing herself, symbolized in cutting off her hair, and proceeds toward reconstructing truth that rested basically on conventional traditions. 
Pilate separated herself physically and socially from an inconsiderate society- that includes her brother and his like. So, ironically, it is her isolation from the materialistic alienated postmodern society that furnished Milkman's own unity with true authentic brethren in Shalimar. Pilate has already owned herself and instead of acquiring property, she has created her own song that unconsciously transmits he family lore. Unlike her brother, Macon Dead, Pilate never washes her hands free of her history. Her own vision of time is cyclical, as she always clings to her past through songs, stories and a bag of bones. Her philosophy in life is that " one's sense of identity is rooted in the capacity to look back to the past and synthesize it with the present" (Smith 276). Being the ancestral figure in the novel, Pilate "pilots" Milkman toward his roots. She directs him to his "authentic existence. From birth, her life has been a continuum of selfactualization"(Hudson-Weems 61).

In Beloved, Baby Suggs performs the same function of Pilate i.e. the ancestral figure. Through self-creation, she demonstrates the move from dismemberment to 're-memberment'. Moving to 124 Bluestone after spending all her life under bondage, Baby Suggs decides to preach "because slave life had busted her legs, back, head, eyes, hands, kidneys, womb and tongue" (Beloved 87). What is left to her is her heart. She claims her freedom by claiming her body as well as her own unique qualities. Though she is not African by birth, she is able to create her own folk religious practice, which is the Clearing. When Baby Suggs preaches to the huddled freed slaves, free blacks and escaped slaves in the Clearing, the people hear a radically different message about themselves from that they hear from white society. Her ceremony in the Clearing disposes the communal unity and the individual power to 're-connect' broken psyches and bodies as well. 
Still, being in the Clearing does not completely release those people from oppressive and racist feelings. But, hearing a different accounting of themselves is essential for preparing them to survive, and to join together. In structure, the ceremony resembles a jazz performance in the sense that it comprises three main parts; namely, men's dancing, children's laughter, and women's weeping followed by Baby Suggs's solo about the urgent need to love one's soul and body. This solo is then developed to a dance to which the community provides the music. This Clearing practice is directly related to the "antelope dance" that Sethe remembers as her mother's and her people's. Both of these practices provide moments of spiritual relaxation through which the blacks can remember themselves, experience themselves, as whole and free beings. In the Clearing, a New World ritual lead by Baby Suggs, the whole community prays with bodies, voices, and hearts to be allowed to be human.

Baby Suggs preaches the ex-slaves to love their black flesh that the whites despise and to replace shame with pride. She advises them: "love your hands! Love them. [...] more than your life- holding womb and your life- giving private parts, hear me now, love your heart. For this is the prize" (Beloved 89). In her speech, Baby Suggs has utilised 'love' as her keyword for 'freedom'. Here she echoes James Baldwin when he explains the meaning of the word "integration" which denotes that "we, with love, shall force our brothers to see themselves as they are, to cease fleeing from reality and begin to change it" (23). In addition, Baby Suggs is Denver's referent ancestral point that frees her. She reaches Denver with her final prophecy. For her, hell is not others, but it is in living without them. The others are the only defense. With these ideas implanted in mind by her grandmother, Denver " go on out of the yard" (Beloved 244) claiming her freedom. 
Through these ancestral figures, characters undergo their journeys of initiation toward freedom. Throughout his journey, Milkman in Song of Solomon learns through Pilate that his ultimate task is to achieve " a strong and centered sense of self that accepts responsibility for his past and reaches out in love for others" (Hover 136). In Shalimar, Milkman learns the true lesson: a person cannot live his present without finding himself a place in the past i.e. without knowing his roots. In fact, Morrison's Solomon clearly denotes the ultimate "significance of shared history communicated by shared stories, shared traditions, and shared experience" (Mason 182). That is why he has to listen to many stories and many voices e.g. Macon, Pilate, Hagar, Ruth, etc. along his journey. In fact, these multi-voiced stories indicate his own indecisiveness and incompleteness. Thus, by only synthesizing all these voices and stories, and admitting them to be his own does he reach his goal. Milkman realizes that it is only his history and his community that could refill this space inside him called 'identity'. Consequently, escaping history is of no use.

Moving to Beloved, one finds that though the past is a powerful rip tide which endangers the lives of both Sethe and Paul D., they must blend their past memories and experiences into their present lives so that they can truly demand their freedom. To achieve freedom, they have to know first that their history has got its positive as well as its negative aspects, and that they suffer because they sent off the memories that might support them spiritually to the same forbidden area as those that might destroy them. So, they have to retain for themselves these positive aspects that would help them to suppress the negative ones. Here comes Orlando Patterson to sum up the whole situation, suggesting that one of the most essential psychological needs for the free ex-slaves is to fill in the absences created by slavery to reconnect with their ancestral pasts, their friends, their living and dead relatives, and their own "conscious community of memory" (5). 
For a black man to acquire an identity, he must first purify himself from and ' whiteness'. He should be convinced that a new other self is to be created. Yet, he should realize that it is only himself who could do it. In Song of Solomon, to realise his quest, Milkman "must undergo rituals that will strip him of his false culture and prepare him for authentic knowledge [...] he has to participate in a hunt. This serves as the male initiation rite [in which]... he is stripped of all the symbols of the dominant culture" (Byerman 116). With the help of his Aunt Pilate, Milkman learns to stretch his horizontal and vertical vision; he starts to question his father's linear conception of time. He comes to know that his real freedom lies not only in his future but also in his past. When he launches his journey to search for the gold, Milkman ironically believes that gold will grant him "cleaned lined self" (Song 220), something that will turn true as it is this journey that will drive him toward his roots.

Milkman's journey is not restricted to reaching Pilate's house i.e. reaching her vision, but it must continue to Shalimar, his ancestral home. There, he knows that he is a grandson of Jake, the youngest son of Solomon, and that his long-lived dream of flight is nothing but a part of his ancestral legacy. But first, he has to pass through his rites of passage successfully. For Milkman, however, it is not enough to reach Shalimar, or to lose his material possession while he is there. He must get rid of the vanity that weighs him down; he must get rid of any sense of 'whiteness' in him in order to be able to create his black self. He has to walk that lonely valley where "there was nothing...to help him- not his money, his car, his father's reputation, his suit, or his shoes. In fact, they hampered him" (Song 227). Accompanying Milkman throughout his journey, one easily recollects DuBois's words that could be applied here: "In those somber forests of his striving his own soul rose before him, and he saw himself some faint revelation of his power, of his mission. He began to have a dim feeling that, to attain his place in the world, he must be himself, and not another" (20). 
Again, in Beloved, Morrison stresses the importance of assuming responsibility in molding an identity. Here, Denver assumes responsibility for protecting her mother from Beloved. So, she was obliged to "leave the yard; step off the edge of the world, leave the two behind and go ask somebody for help" (Beloved 243). Realizing that it is not only Sethe's but it is also her happiness that relied on her getting a job, Denver starts to feel a 'self' born inside her. In fact, it is responsibility that gives the characters a new sense of the self. For Denver, " it was a new thought, having a self to look out for and preserve" (Beloved 252). As the first 'un-enslaved' generation, she represents possibilities for the future. Consequently, Denever has got her own responsibility to break the bond between her mother and her people, and their destructive history: Sethe and Beloved.

Also, in the case of Sethe, it is only when she assumes responsibility for her crime that she could now reconsider its dangerous claims, and avoid it. As Mae G. Henderson suggests, Sethe's attempt to get rid of Bodwin shows that she has managed to achieve some sort of identity that makes her differentiate between what she wants to protect and what she should protect it against; "Sethe, in effect, re-enacts the original event", yet she "directs her response to the threatening 'Other' rather than to ' her best thing' " (81). So, it is responsibility that prepares people for their new selves; it is a pre-condition that 'freedom' necessitates. One could easily notice that through depicting male and female heroic characters, Morrison obliges her readers to see "the value of a life that is authentic because the individual assumes responsibility for self" (Hudson-Weems "Introduction" $\mathrm{x}$ ).

Echoing existentialist writers Morrison is all the time emphasizing the role of responsibility in the context of freedom. Existentialism is bound to the fact that though the external circumstances are determined; though the physical existence is determined, it is one's responsibility to arrange the items once again to make up his own essence. However, though freedom is absolute, it is 
not arbitrary i.e. though there are no rules to restrict, there are values that people have agreed upon within their process of arrangement. From here springs the important role of people or community in highlighting the criteria within which each person's responsibility is created and his freedom is framed. In Morrison's both novels, the communal element dominates the background of the action. The significance of the community in Morrison's work is emphasized with both its positive and negative aspects.

In Song of Solomon, Morison mixes both aspects when she portrays a community that isolated Pilate because of her navel-less belly and a community that guided Milkman toward discovering his origins. It is only when people 're-connect' themselves to their community that is ruled by love and responsibility, either personal or communal, that they could reach their freedom. Always, it is the negative aspect of the community that is stressed while characters are still in bondage. Like Milkman in Song of Solomon who is brought up in a selfish narcissist society that is materialistically and spiritually dead, Sethe in Beloved is first betrayed by her own people who did not warn her at the Schoolteacher's coming and is next isolated by them to live alone haunted by her past embodied in the baby ghost. On the other hand, Milkman starts to feel his identity only in Shalimar within the Black community that still retains its folkloric heritage through names, stories and songs.

In Beloved, Denver is set free from the grips of her mother's history only when she goes out to the outside community that succeeds at last in exorcising Beloved. Developing relationships of her own, and re-establishing connection with the community, Denver realizes for the first time that she has a self that she should work to sustain. However, this new sense of 'selfhood' "might not have occurred to her" without Nelson Lord, a young man whose questions about her time in prison with her mother "blocked up her ears". When the man asks her to "take care of [herself]", he "open[s] her mind" (Beloved 252). This new self 
makes Denver immerse herself more into Cincinnati, where she tells the whole story of 124 Bluestone in order to get help. A number of African women become determined to restore order between two worlds by obliterating "past errors" from "taking possession of the present" (256). Hence, they produce the song and the music they withheld from Sethe after the murder in order to exorcise the ghost.

Within the community in Shalimar, Milkman, for the first time, feels a sense of belonging. He gains direction and purpose, and even a greater sense of his own life. In the wilderness, after losing all his articles, he feels himself a part of the land itself "laughing...he found himself exhilarated by simply walking the earth, walking it like he belonged on it; like his legs were stalks, tree trunks, a part of his body that extended down down down into the rock and soil and were comfortable there" (Song 284). What is important is that he starts deciphering a song sung by the children. To his wonder, he finds that it comprises the narrative of his family. The children's song is the folktale of Solomon, the flying African who one day realizes his extraordinary magical powers and uses them to fly from slavery back in time to his 'African Home'. This leads to the importance of considering the ruling and dominant image that controls the text from the very beginning and that knots the structure of the novel into a cyclical form.

In Morrison's work, it is the folkloric element that connects past and present; the personal and the communal. Morrison writes to tell her readers that Black Americans are no more passive victims because portraying them as such ignores what Lawrence W. Levine speaks of in his Black Culture and Black Consciousness as the " enduring strength" of the cultural "cohesion" that existed and still exists among African Americans (xi). African Americans already have what makes them responsible for their plight. They have a folkloric heritage that makes up their own culture, and differentiates it from the American one. Levine continues suggesting that the beliefs of traditional folk invite an immediate attraction because they sustain the slaves with "sources 
of power and knowledge alternative to those existing within the world of the master class" (63). He goes on saying the continual cultural mixing of European and African "socio- religious attitudes[ ...] resulted in a style which ... [as a whole] was uniquely the slaves' own and defined their expressive culture...at the time of emancipation" (135). This unique cultural style was outwardly practised through music and storytelling. In Song of Solomon, as well as in Beloved Black American folkloric elements merge and are all intermingled in one identifying whole.

As Wilentz emphasizes, Toni Morrison's style in general comprises key factors of "African modes of storytelling" which offer "a way of bridging gaps between the Black community's folk roots and the Black American literary tradition" (61). In Song of Solomon, Milkman Dead throughout his journey is to listen to many stories told by many voices, and he is to reach freedom only when he is able to internalize all these stories within him as a part of a culture he is a part of. Also, in Beloved, Sethe starts her own journey when she starts to retell stories about her past memories which she is "afraid to remember but ashamed not to" (Beloved 159). Sethe, like the novel itself, follows one of the basic principal narrative strategies of any story. She " drops an unexpected fact on the reader, veer away into other matters, then circle back again, and so on" (Page 35). This element of suspense is intended not only as a conventional technique, but also as a reflection of the fragmentation of the experience narrated through the separate pieces of information told not at once but at different intervals of time. It is also intended to postpone the reader's judgement on Sethe. Being so attached to storytelling, music evolves as the second folkloric element to be considered in Morrison's selected novels. 
In Morrison's work the musical element is so dominant that it goes into the thematic bark of both Song of Solomon and Beloved. In Song, for instance, the action starts by Pilate singing her "Sugarman" blues song and ends by Milkman's improvised "Sugargirl" song. Joyce Wegs views that Morrison's Song of Solomon initiates two literary devices, namely, storytelling and music. He suggests that Song of Solomon is a blues song "disguised as a novel". Morrison's use of Pilate's "Sugarman" blues song is considered a clear mark of Morrison's aim to sing the blues in writing. Named after the chief musical instrument associated with the blues, the character of Guitar, provides an additional musical connection (Wegs 212). In fiction, music performs a "function of the perception schema formed by the collective musical experiences"(Glover vi). Yet, in Song, Milkman's great grand-mother who is overcome by sorrow, does not succeed in performing this traditional function, culminating to the Dead family's ignorance of their past.

Here comes the importance of the past with all its aspects. It is significant here to mention that memorizing the words of the song that comprise the history of his family and singing it, Milkman fully realises who he is. It is only when Milkman is able to complete the lyrics of the song Pilate has only partly known that he could achieve his freedom, and that he could help Pilate to complete hers by taking her to Shalimar, to Ryna's Gulch and Solomon's Leap where she could finally bury her father's bones. Though these are the names of two places, Ryna's Gulch and Solomon's Leap support the thematic content. Morrison locates these two places in such a way that "Ryna's Gulch, as well as the bodies of the women Milkman has exploited points to Solomon's Leap" (Dixon 136). So, Milkman must first assume the responsibility for all those women e.g. Ruth, Hagar, Pilate, he has stepped over to make his leap. Together, Pilate and Milkman proceed to the higher ground of Solomon's Leap in order to bury the bones of Pilate's father. Pilate flies (is killed by Guitar) without ever leaving the ground, comforted by Milkman's singing his own 
refashioned song that is fused within the main texture of the narrative. Now Milkman can ride the air as he leaps toward Guitar who is seeking his death.

In Beloved, Morrison's portrayal of captive and freed slave characters producing African music, from field hollers to blues pinpoints the extreme significance of music performances in the lives of those condemned to slavery and those emerging from the trauma of bondage. In Beloved, songs play a very notable role in the text. The songs that Sethe and Paul D. sing are hybrids of American and African elements. Such songs give them release to express their own experience of bondage at the same time of deriving a support from their African presence that the songs imply. They are also considered a musical and verbal mark that Sethe identifies her children with. Such are the songs that she had supplied her own tune for and consequently her unique self.

The third kind of folkloric elements that Morrison works heavily on is the folktales. In fact, one of the most interesting methods that Morrison has used to emphasize the aspects of flight as central in her Song of Solomon is playing on "All God's Children Got Wings", an African American folktale and the "Daedalus/Icarus" Greek myth. To sing that song (of Solomon), Morrison makes use of a traditional slave myth of an African tribe whose people could fly as a framework. In The Book of Negro Folklore, the tale recounts that one day a merciless master purchased a number of African people and he worked them savagely. Given birth to her first child, a woman was repeatedly stricken by the supervisor when she fainted from oppressive heat and excessive work. When the woman fainted again, the slaveholder flogged her. At those moments, she sprang to a great height into the air at a signal from the oldest man in the group, and she flew away. Then all the slaves imitated her and "leaped into the air with a great shout; and in a moment were gone, flying, like a flock of crows" over the fields and back to Africa (Hughes 64). 
Morrison's Song starts with an echo of that aforementioned traditional slave myth. An insurance agent named Robert Smith declares that he will "fly away on [his] own wings"(3) from the roof of the Mercy Hospital. On the prearranged afternoon, some people gather to see as Mr. Smith prepares to spread his blue silk wings and fly over Lake Superior. It happens that an expectant woman in the crowd named Ruth is about to give birth as the winged man springs himself into the air and fell to his death. The next day born child is forever affected by the circumstances of his birth, for "when the little boy discovered, at four, the same thing Mr. Smith had learned earlier- that only birds and airplanes could fly... he lost all interest in himself" (Song 9). Christened Macon Dead III, and named Milkman because his mother breastfeeds him more than 4 years, this child lives all his life in search for the wings that will eventually grant him the power of flight.

In Song of Solomon, there is also the reference to the Daedalus/Icarus Greek myth. Daedalus, a well-known architect in Athens, was ordered one day by King Mines to build him a labyrinth in Crete. After finishing it, Daedalus is jailed within it. In order to escape, Daedalus made two pairs of wings using wax and feathers- for himself and his, Icarus. On their journey to Athens, Icarus tried to challenge the sun, even though his father had warned him not to do. He was told that if he got too close to the sun, the wax in his wings would melt, and he would lose the ability to fly, and that if got too close to the sea his wings would dampen and would also lose the ability to fly. Ignoring Daedalus's warning, Icarus flew too high and the sun melted the wax that held his wings together. Icarus fell into the Aegean Sea and died. 
In Song of Solomon, Solomon is Daedalus in the Greek myth, a slave working in the cotton fields in the South. Leaving behind Ryne, his wife, and their twenty other children, Solomon decides one day to fly back to Africa with his youngest son Jake. "Black lady fell down on the ground/ come booba yalle, come booba tambee/ threw her body all around/come konka yalle" (Song 303). The wife starts crying but Solomon does not return. However, while Solomon is flying, he drops Jake, who unlike Icarus, survives his fall. It is only when Milkman unlocks the mystery of his grandfather and recognizes that he was able to fly that he regains his confidence: "He could fly! You hear me? My great granddaddy could fly" (Song 328). However, Milkman's flight is not the same as his grandfather's. Solomon's flight has proved a lack of responsibility because he flies leaving behind him his family insecure. On the other hand, Milkman gets to know that even if it is impossible to fly, the fantastic dream itself has satisfied in him the need to face problems instead of escaping them altogether. Milkman does not fly in order to escape because he has at least heard "anything the earth had to say" (Song 279). Now, he knows that earth is bound to the sky; that though Pilate dies, she "flies' "without ever leaving the ground".

Like Icarus, Jake falls because he challenges the sun that may be easily linked here with the white society. Jake, the Black man, has kept on coming closer to the white man to the extent of internalizing the humiliating images he has drawn for his own community. Thinking that the White man is the only master, some Blacks work on coming nearer to him separating themselves from their fellow folks. Jake has ignored his father's piece of advice and gone far toward the sun, as some AfroAmericans have gone far trying to immerse themselves into the white society thinking that it is the only route for freedom. Thus, flying in Song of Solomon has not only served as a symbol of self-distinction but most importantly as a "collective experience" (Bruck 297). The father has also warned against the sea that lies beneath. Falling into the sea here symbolizes the degrading, the zero image; a state of being in which Blacks are satisfied with their state as 'niggers'. 
Framed by the celestial flight imagery, Song of Solomon opens with Robert Smith's aborted take-off, that he promised to be from "Mercy" [hospital] to the other side of Lake Superior"(Song 3). Watching Robert Smith with his blue silk wings, the reader also hears Pilate singing: "O, Sugarman done fly away/ Sugarman done gone/ Sugarman cut across the sky/ Sugarman gone home" (Song 9). This is the song that Milkman supplies the tunes of only at the very end discovering that the Sugarman is nobody but his grandfather, Solomon. In the meantime, there is a baby "a little bird" being born. Inside the Mercy hospital, he is the first black baby to be born there inside. The novel proceeds then following this baby's growth till it ends by him making his own leap.

As a result, along the novel, there has been a thread running from Robert Smith to Milkman. By the end of the novel, Milkman flies using his own wings; he no longer needs Robert Smith's silk wings nor does he need Pecola's blue eyes in The Bluest Eyes in order to assert his identity. He flies only after he supplies the tunes for Pilate's song heard at the very beginning. While Robert Smith's flight is an intentional escape that brings about his planned suicide, Milkman's brings about his newborn self. In fact, Mr. Smith fails to assume his responsibilities for a 'being'. As he "had lost his balance for a second" (Song 3), Milkman, in the last scene, throws himself voluntarily into the killing arms of his friend. So, unlike Mr. Smith's, Milkman's flight is not a flight from but a flight of responsible freedom.

However, Morrison leaves her novel open-ended as another support for the important roles that responsibility and wholeness play within the whole context of freedom. Reading Song of Solomon from cover to cover, the reader does not know whether Milkman survives his fall or not; whether it is Guitar who kills him or whether it is Milkman who kills Guitar. In fact, this open-endedness is intended by Morrison who writes: " In the same way that a musician's music is enhanced when there is a response from the audience [...] I have to provide the 
places and spaces so that the reader can participate" ("From Rootedness" 199). What is most important for Morrison is what Milkman has achieved. Since Milkman "has achieved [...] connectedness, it does not matter whether [he] survives his encounter with Guitar" (Duvall 111). What really matters is Milkman's ability to make his own leap; it is his ability to spread his own newly made wings which history has endowed by feathers of freedom and responsibility. Here echo Du Bois's words when he says:

If, however, the vistas disclosed as yet no goal, no resting-place, little but flattery and criticism, the journey at least gave leisure for reflection and self-examination; it changed the child of Emancipation to the youth with dawning self-consciousness...self-respect. (20)

Unlike Robert Smith who flies to escape, Milkman flies to reconnect himself with his ancestors, with Solomon; Milkman flies to his ancestral home in Africa; Milkman flies into the arms of his community even if they may be killing.

The last scene in Song of Solomon introduces a new Milkman who flies and faces his problems fully aware of his responsibility toward himself and his people; he is ready to die, but never to surrender. It is in Song of Solomon that " by discovering his name and performing the song that redeems him and helps him to fly, Milkman completes the unrealized gestures and dreams of Pecola [in The Bluest Eye] and Sula [in Sula] " (Dixon 130). So, Milkman is a 'Morrisonian' character that succeeds in locating himself within a tradition that feeds him with personal freedom and communal 'oneness'. Flight, for him, is no longer a fantasy, but a significant part of the legacy his ancestral past has left him; something that represents a spiritual rebirth. His life now is not that important, as: "Without wiping away the tears, taking a deep breath, or even bending his knees- he leaped...he wheeled toward Guitar and it did not matter which one of them would give up his ghost 
in the killing arms of his brother. For now, he knew what Shalimar knew: If you surrendered to the air, you could ride it" (Song 337).

Had Morrison put an end to her novel, Milkman would have lost, in a sense, what Kimberly W. Benston calls the mythic outline of heroic generation. This begins in a "birth shrouded in mystery, an expedition into a seemingly precultural wilderness, and after an uncertain beginning, willed struggle to assert individuality" (Benston 94), and ends in a leap from Solomon mountaintop, the result of which is hidden from the reader; nothing is openly said. In fact, it is the unsaid that Morrison is always interested in. Finally, it is the ambiguity of the ending of Song of Solomon that brings the significance of the theme. This ambiguity makes the reader ask whether the novel is optimistically emphasizing that one could ' learn' to fly or that it is pessimistically confirming that flight is a mere delusion.

Deciphering the ending of Song of Solomon, one has to take a pensive look at Pilate's death. Throughout the whole novel, Pilate has been providing Milkman with the ultimate example of authentic existence. From birth, she is the ancestral figure that guides Milkman along his journey of salvation. This is Pilate who opens the novel singing for Robert Smith ' O, Sugarman'. Pilate is presented in the novel as a symbol whose navel-less belly was a clear mark that "she was not born from human woman- in mystical terms, she is Earth, the Mother of all" (Freiert 165). So, to end the novel by killing "Mother Earth", Morrison aims at a balance. Though Milkman is, at least, able to fly, Pilate dies. In fact, the "killing of Pilate- the character designated by the narrative as a natural healer- suggests the text's inability to heal the deep emotional wounds that result from collective black shame and trauma" (Bouson 99). By having Pilate killed, Morrison has escaped idealizing her novel that she has given a mythic imprint by enabling Milkman to fly. 
In Beloved, though Sethe is both physically and spiritually dejected at the end of the novel, many readers attribute Paul D.'s return as a happy ending for her. Yet, through the ambiguity of the "Me? Me?" that closes the novel, confidence in a happy future is shaken. The novel does not delineate whether Sethe will find an outlet to value herself and claim her "best thing" (Beloved 273). In Toni Morrison's works, resolutions always seek: "an ideological solution to the fundamental contradictions that animate the work. Any resolution can have traces of the conflicting materials that have been processed within it. It is where subtexts and repressed discourses can throw up one last flare of meaning" (Plessis 3).

Because she is portraying a 'word-less' experience or a 'wordless' history, Morrison's Beloved presents a challenge to America's assumed belief in the pastness of the past by shaking confidence in the resolution of historical trauma. Because slavery constitutes one of the painful and shameful points, if not the most painful and most shameful, in the American history, Morrison here in Beloved emphasizes that this point is never passed simply because Sethe ends the novel standing at the middle between past and future. The shame of the experience will never pass away.

To conclude, though Song of Solomon and Beloved portray two different stages in the lives of Afro-Americans, they both introduce their characters as undergoing their own journeys toward freedom in a postmodern world characterized by fragmentation, detachment and displacement. In both novels, characters seek freedom either through emersion in history as in Song of Solomon or escaping from it as in Beloved. However, history evolves as a ruling principle that all the time has its own positive aspects that keep people safe providing them with a cultural identity that induces them with a personal one. Yet, though freedom is a personal dream in the first place, it converts to nothing if isolated from the more comprehensive collective communal vision. It 
needs the community to feed its hunger for support the same as it needs the individual to frame up its strife for distinction.

\section{Works Cited}

1. Abel, Elizabeth. " Race, Class, and Psychoanalysis? Opening Questions" in Conflicts in Feminism. Ed. Marianne Hirsh. New York: Routledge, 1990.

2. Baker, Huston A. Jr. "When Lindberg Sleeps with Bessie Smith: The Writing of Place in Sula" in

3. Toni Morrison: Critical Perspectives. Eds. Henry Louis Gates and K. Appiah. New York: Amistad, 1993.

4. Benston, W. Kimberly. " Re-weaving the 'Ulysses Scene': Enchantment, Post-Oedipal Identity,

5. and the Buried Text of Blackness in Toni Morrison's Song of Solomon" in Comparative American Identities. Ed. Hotense W. Spillers. New York: Routledge, 1991.

6. Baldwin, James. The Fire Next-Time. Dial Press, 1963.

7. Bouson, J. Brooks. Quiet As It Is Kept: Shame, Trauma and Place in the Novels of Toni Morrison.

8. New York: University of New York Press, 2000.

9. Bruck, Peter. " Returning to One's Roots: The Motif of Searching and Flying in Toni Morrison's

10. Song of Solomon" in The Afro-American Novel Since 1960. Ed. Peter Bruck and Wolfgang Warter. Netherlands: Gruner Publishing Co., 1982.

11. Byerman, Keith. "Beyond Realism" in Toni Morrison: Critical Perspectives. Eds. Henry Louis

12. Gates and K. Appiah. New York: Amistad, 1993.

13. Dixon, Melvin. "Like an Eagle in the Air" in Toni Morrison: Critical Perspectives. Ed. Henry

14. Louis Gates and K. Appiah. New York: Amistad, 1993.

15. Du Bois, W.E. B. The Souls of Black Folk. U.S.A, Conn: Fawcett Publications, Inc. 1961. 
16. $\quad D u$ Plessis, Rachel Blau. Writing Beyond the Ending. Bloomington: Indiana University Press, $1985 . \quad$ Duvall, John. " Doe Hunting and Masculinity: Song of Solomon and Go Down, Moses". Arizona .Quarterly 47.1 (Spring 1991): 95-115.

17. Freiert, William. "Classical Themes in Song of Solomon", Helios 10 (1983):160-71.

18. Glover, Antoinette Gail. Toni Morrison Literary Music. University of Texas, Proquest Dissertation

19. Publishing, 1996.

20. Henderson, Mae G. "Toni Morrison's Beloved: Re-membering the Body as Historical Text" in Comparative American Identities. Ed. Hotens Spillers. New York: Routledge, 1991.

21. Horvitz, Deborah. "Nameless Ghosts: Possession and Dispossession in Beloved" Studies in

22. American Fiction 17.2 (Autumn 1989):157-67.

23. Hover, Grace A. and Barbra Lounsberry."Flying as Symbol and Legend". CLA Journal xxvII 2

24. (1983): 128-40.

25. Hudson-Weems, Clenora and Wilfred Samules. Toni Morrison. Massachusetts: Washington Square

26. Press, 1966.

a. Hughes, Langston\& Arna Bontemps. The Book of Negro Folklore(1958) New York : Dodd, Mead\& Co,1983.

27. Hurston, Zora Neale. Their Eyes Were Watching God in Hurston: Selections, ed. Cheryl A. Wall.

28. New York: The Library of America, 1995.

29. Krumholz, Linda. "The Ghosts of Slavery: Historical Recovery in Toni Morrison's Beloved". African American Review 26. 1 (Spring 1992): 395408.

30. Lee, H. Dorothy. "The Quest for Self: Triumph and Failure in the Works of Toni Morrison" in Black 
31. Women Writers (1950-1980): A Critical Evaluation, ed. Mari Evans. New York: Anchor

32. Press, 1984.

33. Levine, Lawrence W. Black Culture and Black Consciousness: AfroAmerican Folk Thought from

34. Slavery to Freedom. Oxford: Oxford University Press, 1978.

a. Mason, Theodore O., Jr. "The Novelist as Conservator: Stories and Comprehension in Toni Morrison's Song of Song" in Toni Morrison, (ed.) Harold Bloom. New: York: Chelsea House Publishers, 1990.

35. Morrison, Toni. "Intimate Things in Place: A Conversation with Toni Morrison" in Chant of Saints.

36. Ed. Stepto Robert and Michael Harper. Urbana: University of Illinoid Press, 1997.

37. Morrison, Toni. Beloved. New York: Knopf, 1987.

38. ---. "From Rootedness: The Ancestral as Foundation" in Black Women Writers. Ed. Mari

39. Evans. New York: Anchor Press, 1984.

40. ---. Song of Solomon. New York: Knopf, 1977.

41. Page, Philip. "Circularity In Toni Morrison's Beloved". African American Review 26.1 (Spring

42. 1992): 31-39.

43. Patterson, Orlando. Slavery and Social Death: A Comparative Study. Cambridge: Harvard University

44. Press, 1982.

a. Smith, Valerie. "Song of Solomon: Continuities of Community". Toni Morrison, Louis Henry Gates (ed.). New York: Penguin, 1993.

45. Tajizadehkan, Maryam and Parvin Ghasem "Cultural Identity in Black Subjects: the Emergence

46. of New Black Subjects in Beloved" Journal of African American Studies 23.1 (2019):

47. 217-232. 
48. Wegs, Joyce. “Toni Morrison's Song of Solomon: A Blues Song.” Essays in Literature 9.2 (1982):211-223.

49. Wilentz, Gay. "Civilizations Underneath: African Heritage and Cultural Discourse in Toni Morrison's Song of Solomon". African American Review 26.1 (1992): 61-76. 